\title{
Organizational Politics as Antecedent of Stress in Public Sector Universities of Khyber Pakhtunkhwa
}

\author{
Dr. RANI GUL \\ Assistant Professor, University Of Malakand, Chakdara, KPK \\ Email: dr. rani27@gmail.com \\ Dr. SADIA SULEMAN KHAN \\ Assistant Professor, SBKWU, Quetta, Balochistan, Pakistan. \\ Email: ssuleman_khan786@yahoo.com \\ SHABANA AKHTAR \\ Assistant Professor, SBKWU, Quetta, Balochistan, Pakistan. \\ Email: shabanaakhtar37@yahoo.com
}

\begin{abstract}
This quantitative study aims to examine the relation between organizational politics and job stress among the faculty members serving in different public sector universities of the province, Khyber Pakhtunkhwa, Pakistan. Changes in working environments contribute to job stress. Stresses can be deterred by primary preventance, such as focused job design and growth in administration, secondary avoidance such as learning, etc. Weaknesses are correlated with stress such as work material, work loft, working hours, controls and career advancement, organizational role, interpersonal businesses and employing company tradition. 146 participants were selected using proportionate sampling techniques and data were collected using two different structured questionnaires, Job Anxiety-Stress (JAS) questionnaire consisted of 11 questions, Perceptions of Organizational Politics Scale (POPS) consisted of 12 questions. The hypotheses were evaluated using the Regression and correlation analysis, the results show that a significant correlation exists between organizational politics and job stress. The implications of this analysis are discussed. In this study the implications for the organizational policies and job stress in the at university sector were discussed with a view to improving standards.
\end{abstract}

Keywords: Organizational Politics, Power at Work, Job Stress, Managing Stress, Job Satisfaction.

\section{Introduction}

The negative and adverse effects of organizational politics are well-established in research studies and theory (Hochwarter et al. 2003; Chang et al. 2009; Vigoda- Gadot and Talmud 2010). For effects such as burnouts, commitment turnover targets, satisfaction at work etc. However, there was little research into the effect of organizational politics on workplace stress, which was increasingly recognized as an important mechanism for organizational performance and competitive advantage (Macey and Schneider, 2008; Albrecht et al., 2015; Barrick et al., 2015).

This research investigates the relationship between organizational policies and work stress for employees. Since studies have long stated that organizational politics is an evolving issue and that further research and empirical study are required (e.g., Gandz \& Murray 1980; Mintzberg, 1983; Pfeffer, 1981, 1992). The method of collecting power by different means is organizational politics instead of merit or casualty. This is 
often used in unfair ways to obtain control. It gains all the powers to enrich the income, such as promotion, the acquisition of several funds or other resources or the acquisition of beneficial ventures. Organizational Politics can be seen as a deliberate activity by the people to pick up an advantage to the detriment of others (Kacmar, Bozeman, Carlson, and Anthony (1999). As indicated by Kacmar et al. (1999) there are constantly high politics in such kind of organizational atmosphere where association assets are constrained and there is the testing circumstance for the representatives at the work environment.

Its potential impacts and effects on the results of the workforce are a key consideration for the organizational policy (OP). In theory, politics often interfere with normal processes (e.g. promotions, decision-making, and rewards) and damages performance and productivity on both the level of the organization. It has been misleading to empirically try to back up the concept. Some research has established a negative association between surgery, job behaviours, and stress (e.g. Drory, 1993).

Within organizations, the employees may have disagreements and conflict of interests, which causes competing claims on limited resources (Mishra et al. 2015). Organizational Politics can play the role of the stressor to influence people's attitudes, behaviours and reactions in the working environment. In many studies, the political understanding of justice and equity in an organization has been shown to result in poor work performance (Drory, 1993). The identity to politics within the organization is not an organization's conscience, but an entity's perception of other political practices such as nepotism, stifling competing groups and manipulating the political organization (Kachmar \& Ferris 1991). It makes distinction because it's the fight for authority. Different researchers proposed substantial views in working atmospheres of people (Parker, Dipboye \& Jackson, 2014). Organizational politics is influenced directly and indirectly by the behaviour and attitude of employees working in an organization. Political conduct exists in the association of two sorts relying on the discernments it may be certain or negative. The negative result conduct in the association make the troublesome impact on the representatives and the notoriety of the association coming about worker turnover, low profitability and so on and it can be limited by utilizing organizational equity and making an encouraging relationship with the representatives.

\section{Research Context}

Work Stress
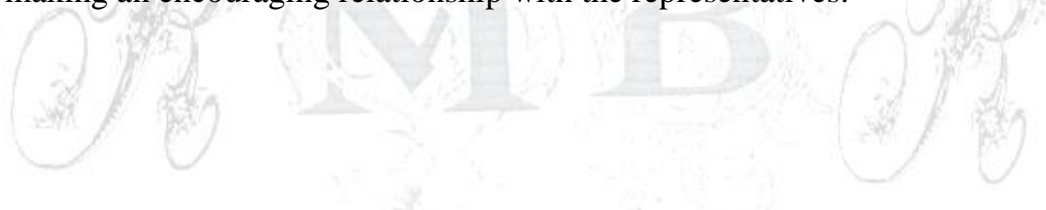

Stress is one of the imperative features in the association that is made when the substantial and passionate capacities of an individual don't coordinate according to the activity requests and it makes a psychological and mental weight on the representatives at the working environment.

In the context of the present study, Stress is the reaction of the body to any change which requires a change or reaction. The physical, mental, and emotional answers the corps responds to these changes (Adamo SA 2014). This stress is expressed, as uncertainty and uneasiness about individual work, ill-health and symptoms of physical health (Spiel Berger, et.al (1983). Stressed people are less innovative, confident, and provocative than those who otherwise affect their relationship. This led to a massive loss for the nation by these individuals (Palmer \& Stephen, 2004). The workers suffer from many causes of job stress (Dollard, Maurean and Jacquee, 1999). There are several sources of stress. One of the key causes of working stress is that the mind and body are impaired. There is a connection between mental harm and significance.

The previous studies have affirmed the negative effects of work stress on the company and economy individually (Ganster and Schaubroeck, 1991; Joure, Leon et.al 1989. Stress costs can be high, due to lost time, decreased production and accidents (Minter, 1991). According; Kahn and Bossier, (1992), There is significant evidence that workplace social environment is commonly correlated with job stress (Beehr, 1985). However, very little foreign research and no study (up to the researcher's knowledge) have looked at perceived organizational politics and job stress in the strict context that the two terms are used here. It is the study of power in action (Pfeffer, 1981). Instead, earlier work focused on related concepts like 'ambiguity,' 
'conflict' and 'control.' That indicates that politics should also be linked to work stress, but does not prove it. The essence of the relationship (if any) is still uncertain. Politics and stress can be believed to be linked positively, but further comprehensive work is required to check this relationship.

\section{Organizational Model of Stress}

F. Parker and Decotiis (1983) proposed C. A model of organizational stress. This model was used as a theoretical framework for the study. Six key stressors perform a notable part in organizational anxiety, as suggested by the proposed examinations. Classification of these stressors appears below.

(1) The condition and environment of the work

(2)Conditions relating to the structure, environment and knowledge flow of an entity

(3) The factors relating to functions

(4) In-work partnerships

(5) Career promotions and development

(6) Social obligations and commitments;

The classification of stressors are like those talked about by Marshall and Cooper (1976) and Ivancevich and Matteson (1980) notwithstanding, the difference between these models is that of organizational and don't regard singular contrasts like a mediator of the stress - stressor connection. The model distinguishes two strength outcomes: the normal one and the second one. The standard level outcome is referred to as stress, whereas the outcomes at the second level are known as individual and organizational outcomes, both affected by stress and predicted by different factors. These second-level results may incorporate decrements in organizational duty, fulfilment, inspiration, and employment execution, and evasion conduct.

\section{Conditions of Organizational Politics}

There are three different conditions of Organizational Politics. The first condition to using organizational politics is interdependence; when stakeholders of an organization affect each other through their activities, it creates organizational politics. The second condition for the use of political behaviour is heterogeneous goals, which are inconsistent with each other. The third condition for the existence of organizational politics is Scarcity of resources. People try to make competitive claims on limited resources and this competition give birth to conflict. All these conditions give rise to political activities like forming coalitions, game playing, controlling information channels, attacking or blaming others etc. Political activities may either produce favourable or unfavourable outcomes for organizations.

Some of the researchers like Mintzberg (1985), have identified some positive effects of organizational politics like overcoming personal inadequacy, coping with change, and better leadership but most studies on organizational politics have mentioned its negative effects like decrease in organizational citizenship, level of job satisfaction, behaviour, Organizational commitment, job productivity, increase in unpunctuality, absenteeism, employee turnover, level of stress and job anxiety etc. (Ferris, et. al 1996; Randall, Cropanzano, Bormann, \& Birjulin, 1994).

In alignment with the majority of the studies on OP (Burns, 1981, Ferris et al., 1989, Mayes and Allen, 1998), the present study will also consider organizational politics as a negative paradigm. Purposely, the researcher shall consider the cognitive approach to study organizational politics. Organizational politics will be studied from the perspective of individual's perception regarding it.

This study has focused on multilevel backgrounds and consequents of organizational politics in higher education division of Khyber Pakhtunkhwa, but its generalization can be made to other provinces of Pakistan since the higher education sector of other provinces also have limited resources with highly diversified workforce having conflicting roles and relationships, which gives rise to the power struggle and 
ultimately results in organizational politics. This will help the policymakers and managers to decrease the negative impact of organizational politics by using different tools and technique. Moreover, it will also help managers/policymakers to improve the performance of the organizations and employees by utilizing the positive impact of organizational politics.

\section{Literature Review}

For the study of the correlation between perceived politics and stress, questionnaires have been utilized with a sample set of 822 employees, in different positions. This study (Ferris et al.; 1994) found a positive connection between perceived politics and employment anxiety. In another research (Cropanzano, Howes, Grandey, \& Toth, 1997), found that policy feeling and job stress seemed to be positively related, but not so when the individual understood the nature of organizational politics. Stress and politics can be thought to be positively related, but more thorough research is needed to track this relationship.

More recent studies indicated that withdrawal habits and turnover intentions were strengthened by politics (e.g., Bozeman et al., 1996), but others observed no such linking (e.g., Parker, Dipboye, \& Jackson, 1995). Few researches have examined issues related to OP in the public sector. Several studies seem at first sight to have done so, but were conducted mainly at universities (e.g. Christiansen, Villanova \& Mikulay1997; Ferris et al., 1996a, 1996B, Welsh \& Slusher, 1986) or in combination with mixed samples of private and semi-public institutions ( e.g., Drory, 1993; Ferris \& Kacmar, 1992; Kumar \& Ghadially, 1989).). Except for Parker et al. (1995), there has been no research investigating the impact of the perceived corporate policies on job stress among the public sector workers in universities.

Tendencies of jobs and education differ considerably from those of semi-public or private companies of public establishments. Public sector organizations typically provide a healthy working climate, improved job security, and some even a fight to serve a wide and varied population. Consequently, there are still unclear and need to reflect on what effect internal politics can have on government agencies and civil servants (Rainey, 1991).

More recent studies have shown that the OP 's approach to the performance of human resources structure and decision-making is related to procedural judicial theory (Folger, Konovsky, \& Cropanzano, 1992). In these systems, lack of social justice and fairness is the main reason of organizational politics high perceptions and, as such, of impaired organizations.

The Organizational structure should also be taken into account concerning what people think of it, not what it reflects. Therefore, studies have shown that understanding of justice and fairness is a political environment at work and can also be related to a variety of outcomes. Ferris, Kacmar and their colleagues have been widely advocated in numerous studies for such ideas (Ferris et al., 1996a, 1996b; Ferris, Fedor, \& King, 1994; Ferris, King, Judge, \& Kacmar, 1991).

Ferris and her colleagues have been involved. Ferris et al. (1993, Study 1) also found in another study that perceived political and labor stress are often ively linked, but less so when the indiscreet understands organization politics. Politics and stress may be thought to be positively related, but further systematic work is required to check this correlation.

\section{Research Objectives}

Objectives of the study were:

1. To investigate, how organizational politics affect job stress.

2. To evaluate organizational politics as an antecedent of stress in public universities of KPK. 


\section{Research Methodology}

\section{Participants and Setting}

The Population of the study consists of the academic faculty members serving in public sector universities of Khyber Pakhtunkhwa. Due to time constraint and limited financial resources, a sample size of 200 academic faculty members of the Department of Management and Information Sciences, Arts and Humanities and Social Science from five different universities of Khyber Pakhtunkhwa were selected through convenient sampling technique. Of the questionnaire distributed to 200 faculty members, 146 were returned. The participants were both male and female. Majority of the participants were assistant professors serving on BPS-19 with an experience of 4-6 years.

\section{Instrumentation}

The closed-ended structured questionnaire with four points Likert scale was used to gather data from the sample participants. The anchors ranged from "1" allocate for "Strongly Disagree", "2 for "Disagree", "3" for "Agree" and "4" for "Strongly Agree" for all the statements in the questionnaire. The survey questionnaire was divided into two divisions, demographic and subjective. The demographic section included gender, age, and level of qualification, job title, job status, and payscale. Multiple Organizational Politics and Job stress of the personnel are included in a subjective segment of the study. The primary data collection technique was used, and the data was collected by the researcher personally following all the ethical considerations like obtaining prior permission for data collection from all concerned faculties' directors, volunteer participation and confidentiality of the participants etc.

In this study, the data contains only two variables; in which one was selected as the independent variable (i.e. Organizational Politics) and the other one was selected as dependent variables (i.e. Job Stress). There were different variables which were identified in the literature review but were not included in the current study. Similarly, the different stressors/determinants of stress discussed in the literature review were also not included in this study because of time constraint. The variables of the study are as follows.

\section{Organizational Politics (Independent Variable)}

For the measurement of organizational politics, the twelve items questionnaire was developed by the researcher with the help of the questionnaire developed by Kacmar and Carlson (1994). This model is known as Perceptions of Organizational Politics Scale (POPS) and used to measure perceived politics in the organization. The questionnaire includes the items such as "Up-gradation in my unit mostly goes to toppers" (reverse-scored), "Favoritism rather than excellence defines who becomes fast in all direction and meanwhile I have worked here. Politically applied policies of promotion and pay I have never seen. Sample items in the questionnaire were (1) Favoritism rather than merit dictates who should go ahead (2) Rewards should still go to the people working best in this business (reverse scored), and (3) My organization has a group of individuals who keep moving because nobody wants to question them. The participants reported how much they agreed with the statements.

\section{Job Stress (Dependent Variable)}

For the measurement of job stress of employees, the subscale Job Anxiety-Stress (JAS) questionnaire developed by House and Rim's (1972) was consulted for help. Originally this questionnaire involved seven items which were measured with a response of true or false. To make it more reliable and add more variance, the balance is improved to five points Likert-type answer plans with 11 statements for job stress variable. 


\section{Reliability Test}

To find out that the scale used in the questionnaire in this study is reliable, the questionnaire was distributed to 40 faculty members of five different universities. The collected data was analyzed in SPSS using Cronbach alpha test. The Cronbach alpha score for all 12 statements in POPS questionnaire was .82 while in JAS questionnaire it was .85 for all 11 statements included in the questionnaire. The overall Cronbach alpha was .83.

\section{Data Analysis}

Data was examined through SPSS version 23. The data was investigated in four stages. In stage-I, the demographic profile of the dependents, mean, standard deviation and reliability test (Cronbach's Alphas) of all the variables used in the study were examined. Pearson correlation and Variance Inflation Factor test are run to test the associations amongst the variables are analyzed in stage-II. In stage-III, for dependent variable regressed on the independent variable, the assumptions of multiple regressions were tested. Finally, in stage-IV, Regression analysis was used to find the impact of organizational politics on job stress in Khyber Pakhtunkhwa's different public sector universities.

\section{Results}

\section{Demographic Information}

The first demographic question in the survey collected information on the gender of the participants.

Table 1: Demographic information

\begin{tabular}{|ccccc|}
\hline Demographics & Classification & Frequency & Percentage & $\begin{array}{c}\text { Cumulative } \\
\text { percentage }\end{array}$ \\
\hline Gender & Male & 135 & 92.46 & 92.46 \\
Age & Female & 11 & 7.54 & 100 \\
& 25 years - 35years & 09 & 6.17 & 6.17 \\
& 36 years - 45 years & 98 & 67.12 & 73.29 \\
& 46 years - 55 years & 20 & 13.69 & 86.98 \\
3 Qualification & above 56 years & 19 & 13.02 & 100 \\
& Bachelor & 0 & 0 & 0 \\
& Master & 12 & 8.22 & 8.22 \\
& MPhil/MS & 78 & 53.42 & 61.64 \\
4Job Title & PHD & 56 & 38.36 & 100 \\
& Lecturer & 23 & 15.75 & 15.75 \\
& Assistant Professor & 69 & 47.26 & 63.01 \\
& Associate Professor & 40 & 27.40 & 90.41 \\
5 Job Status & Professor & 14 & 9.59 & 100 \\
& Permanent & 125 & 85.62 & 85.62 \\
& Temporary & 12 & 8.22 & 93.84 \\
& Contract & 9 & 6.16 & 100 \\
6 Basic Pay Scale & 18 & 23 & 15.75 & 15.75 \\
& 19 & 69 & 47.26 & 63.01 \\
& 20 & 40 & 27.40 & 90.41 \\
& 21 & 14 & 9.59 & 100 \\
\hline
\end{tabular}

$135(94.4 \%)$ participants reported their gender as male while 11 participants $(7.54 \%)$ described their gender as female. Descriptive statistics revealed the mean value of gender at $1.07 \%$ with a standard deviation of $0.26 \%$. The finding reveals the majority of the respondents are male. 
Additional information regarding respondents age, high level of qualification, a post held, the status of the post, and basic pay scale. Table- 2 presents the frequencies and percentages of all the information gathered from participants. A short review of table 2 demonstrates that 9 respondents are of the age of 25-35 which is $6.17 \%$ of the entire respondent. Similarly, $98(67.12 \%)$ respondents were found with the age of $36-45,20$ $(13.69 \%)$ participants with the age ranging from 46-55and $19(13.02 \%)$ participants reported their age 56 and above. Findings on respondents' qualification hint that $12(8.22 \%)$ respondents have master's degree, $78(53.42 \%)$ did MS/M-Phil and 56 (38.36\%) respondents have a degree of PhD and Post Doc.

The results further highlight that in terms of job status, the majority of the participants (47.26\%) estimated their job as an assistant professor, while 23(15.75\%) respondents reported their job as lecturers, 40 $(27.40 \%)$ as associate professor and $14(9.59 \%)$ as a professor. The overwhelming majority $125(85.62 \%)$ of the respondents were Permanent, $12(8.22 \%)$ are Temporary and $9(6.16 \%)$ are a Contract faculty member in public sector universities of KPK. Similarly, the basic pay scale of the majority of the respondents was 19, while 23 of them had BPS-18, 40 faculty members had BPS-20 and 14 have BPS-21.

\section{Hypothesis Results}

H 1: Organizational politics have a positive influence on job stress

H 2: Organizational politics has a detrimental impact on job stress

\section{Diagnostic Test for Multicollinearity}

To find out whether there is multicollinearity exist among the variables, the Variance Inflation Factor (VIF) test is used. It is also used to support the legitimacy of the regression analysis. If the value of VIF is below five, it recommends that there is no multicollinearity exists among the variables (Gujrati, 2003). Thus the VIF test is used to find out the multicollinearity among the variables used in this study. The result of the VIF is given in table 2. The result shows that VIF is reasonably good. The value tolerance is one and VIF is also one, thus it means that there is no collinearity among the variables of the model.

Table 2: Variance Inflation Factor

\begin{tabular}{|c|c|c|c|}
\hline Model & & Collineari & \\
\hline & & Tolerance & VIF \\
\hline 1 & Organizational Politics & 1.000 & 1.000 \\
\hline
\end{tabular}

a. Dependent Variable: Stress

Table 3: Collinearity Diagnostics

\begin{tabular}{|llllll|}
\hline Model & Dimension & Eigenvalue & Condition Index & \multicolumn{2}{l|}{ Variance Proportions } \\
\hline & & & & (Constant) & OP \\
& 1 & 1.998 & 1.000 & .00 & .00 \\
1 & 2 & .002 & 31.174 & 1.00 & 1.00 \\
\hline
\end{tabular}

a. Dependent Variable: Stress

\section{Correlation Matrix}

Correlation analysis is used for the purpose to find out the association between the dependent and independent variable. Thus, the following table- 4 show results of correlation analysis for the current study. 
Table 4: Correlations

\begin{tabular}{|llll|}
\hline & & Organizational Politics & Job Stress \\
\hline \multirow{3}{*}{ Organizational Politics } & Pearson Correlation & 1 & $.210^{*}$ \\
& Sig. (2-tailed) & & .011 \\
& $\mathrm{~N}$ & 146 & 146 \\
& Pearson Correlation & $.210^{*}$ & 1 \\
Job Stress & Sig. (2-tailed) & .011 & 146 \\
& $\mathrm{~N}$ & 146 & 146 \\
\hline
\end{tabular}

Table-4 shows that the value of the correlation between independent variable organizational politics and dependent variable job stress is 0.210 which concludes that there is a moderate positive relationship between these two variables. Moreover, the result also suggests that if we increase the organizational politics it will also increase positively the level of work stress of the employees.

Table No 5

\begin{tabular}{|llllll|}
\hline Model & Sum of Squares & DF & Mean Square & F & Sig \\
\hline Regression & 2.311 & 1 & 2.311 & 6.623 & $.011^{\mathrm{b}}$ \\
Residual & 50.256 & 144 & .349 & & \\
Total & 52.568 & 145 & & & \\
\hline
\end{tabular}

Table No 6 Anova

\begin{tabular}{|llllll|}
\hline Model & \multicolumn{2}{ll}{ Unstandardized Coefficients } & Standardized Coefficients & T & Sig. \\
\hline & $\mathrm{B}$ & Std. Error & Beta & & \\
(Constant) & 4.342 & .763 & 1 & 2.311 & 6.623 \\
Organizational & .626 & .243 & 144 & .349 & \\
Politics & & & & & \\
\hline
\end{tabular}

Dependent Variables: Stress, Predictor: (constant), Organizational Politics

Table 7: Model Summary

\begin{tabular}{|c|c|c|c|c|c|c|c|}
\hline & $\mathrm{R}^{2}$ & Adjusted $\mathrm{R}^{2}$ & Std. Err of the e & Change Stat & stics & & \\
\hline \multirow[b]{2}{*}{$.210^{\mathrm{a}}$} & \multirow[b]{2}{*}{.044} & \multirow[b]{2}{*}{.037} & \multirow[b]{2}{*}{.59077} & $\mathrm{R}^{2}$ Change & F Change & df1 & Sig. F Change \\
\hline & & & & .044 & 6.623 & 1 & .011 \\
\hline
\end{tabular}

Dependent Variables: Stress

Table 7 shows the overall model summary of the study. According to the results of the above table the value of $\mathrm{R}=0.210$, it means that there is a $21 \%$ variation exists between organizational politics and job stress. The coefficient of determination R Square has a positive value of 0.044 which indicate that there is a $4 \%$ linear relationship between job stress and OP.

ANOVA indicates the level of significance of the dependent and independents variables used in the study. The result of ANOVA is given in table 7. According to the result, the value of "P" is less than 0.05 , thus it means that the impact of organizational politics on job stress is vastly significant.

\section{Regression Coefficients}

Regression analysis is usually used for the measurement of the impact of the independent variable on the dependent variable. The study uses the linear regression analysis for the measurement of the impact of organizational politics on job stress. The results of the regression coefficients are given in the below table. 
Table-7 shows the results of the regression coefficient of the study. The regression coefficient tells us that how much changes bring by direct variable when one unit is changed by an indirect variable. Thus, according to result, the value of B is 0.626 , which means that if organizational politics is increased by one unit it brings $62.6 \%$ change in job stress. Results also show that the value of $\mathrm{T}=2.574$, which is greater than 2 and the significance value is 0.011 which is a lesser amount of required range i.e. 0.05 , thus it also confirmed that there is a significant association between organizational politics and job stress.

\section{Discussion and Conclusions}

Organizational politics exists almost in every organization, whether it is at the private or public educational sector, health sector or any other major department. Moreover, politics whether positive or negative cannot be eliminated within the organization. This study investigated three classes of antecedents of perceptions of organizational politics. These classes were a personal influence, work context/Job influence and organizational influence. It is proposed in the study that OP has a significant relationship with job stress. The results show that OP has a positive impact on job stress. It means that when faculty members perceive that people use political approaches to achieve their goals, using fear or unfear means in the organization, violating the merit, it greatly impacts their performance and such anxieties lead them toward stress. The results are in line with Samad, (2011b), Rashid et al. (2013) and Danish et al. (2014). The results highlight that organizational politics unfavourably affect the organization's environment, thus, as a result, it leads to lack of trust and level of employees' commitment. According to the study of Harris et al (2007), due to lack of conservational fairness and the unclear circumstances produced by the employee's organizational commitment and job stress level increase.

These studies suggest that organizational politics and job stress has a positive relationship and the result of this relationship at the workplace raises the job stress level of the personnel, so this automatically decrease the level of organizational commitment and increases the employee's turnover to other organization. However, the current findings contradict the results of (Danish et al., 2014; Rashid et al., 2013. Their studies sought out $\mathrm{OP}$ and job performance in private universities. are working independently and they have their structure and management system.

The current study has worthwhile implications for human resource manager (HRM) and also for policymakers. HRM can identify the political approaches of the behaviour and keep better check whether their behaviour can affect the contextual or individual task performance of the employees. They can arrange sessions and training for the faculty which can ultimately reduce the level of faculty stress by eliminating the negative effects of OP on employs performance. Additionally, negative effects of OP and job stress can be reduced by developing and enhancing fairness and justice, employee assistance program and rehabilitation program within an organization.

\section{References}

Bandura, A. (1997). Self-efficacy: The exercise of control: Macmillan

Beeh, T. A., King, L. A., \& King, D. W. (1990). Social support and occupational stress talking to supervisors. Journal of Vocational Behavior, 36(1), 61-81.

Beehr, A., T. A., \& Newman, J.E. (1978). Job stress, employee health, and organizational effectiveness: A facet analysis, model, and literature review. Personnel Psychology, 31(4), 665-699.

Block, F., \& Noakes, J. (1988). The politics of new-style workfare. Socialist Review, 18(3), 31-58.

Bozeman, D. P., Perrewe, P. L., Kacmar, K., Hochwarter, W. A., \& Brymer, R. A. (1996). An examination of reactions to perceptions of organizational politics. Paper presented at the Southern Management Association Meeting, New Orleans, LA.

Conner, D. S. (2006). Human-resource professionals' perceptions of organizational politics as a function of experience, organizational size, and perceived independence. The journal of social psychology, 146(6), 717-732. 
Cropanzano, R., Howes, J. C., Grandey, A. A., \& Toth, P. (1997). The relationship of organizational politics and support to work behaviors, attitudes, and stress. Journal of organizational behavior, 159180.

Dahl, R. A. (1957). The concept of power. Systems Research and Behavioral Science, 2(3), 201-215.

Danish, R. Q., Humayon, A. A., Aslam, N., Usman, A., \& Tariq, M. I. (2014). Employee's Perceptions of Organizational Politics and Stress at Workplace; A Comparative Study of Public and Private Sector Universities. Research Journal of Recent Sciences ISSN, 2277, 2502.

Drory, A. (1993). Perceived political climate and job attitudes. Organization Studies, 14(1), 59-71.

Fedors, D., Ferris, G. R., Harrell-Cook, G., \& Russ, G. S. (1998). The dimensions of politics perceptions and their organizational and individual predictors. Journal of Applied Social Psychology, 28(19), 17601797.

Ferris, G. R., \& Kacmar, K. M. (1992). Perceptions of organizational politics. Journal of management, 18(1), 93-116.

Ferris, G. R., Adams, G., Kolodinsky, R. W., Hochwarter, W. A., \& Ammeter, A. P. (2002). Perceptions of organizational politics: Theory and research directions The many faces of multi-level issues (pp. 179254): Emerald Group Publishing Limited.

Ferris, G. R., Frink, D. D., Bhawuk, D. P., Zhou, J., \& Gilmore, D. C. (1996). Reactions of diverse groups to politics in the workplace. Journal of management, 22(1), 23-44.

Ferris, G. R., Russ, G. S., \& Fandt, P. M. (1989). Politics in organizations. Impression management in the organization, 27, 143-170.

Folger, R., Konovsky, M. A., \& Cropanzano, R. (1992). A due process metaphor for performance appraisal. Research in Organizational Behavior, 14, 129-129.

Gandz, J., \& Murray, V. V. (1980). The experience of workplace politics. Academy of Management Journal, 23(2), 237-251.

Gilmore, D. C., Ferris, G. R., Dulebohn, J. H., \& Harrell-Cook, G. (1996). Organizational politics and employee attendance. Group \& Organization Management, 21(4), 481-494.

Hackett, R. A. (2001). News media's influence on Canadian party politics: Perspectives on a shifting relationship. Thorburn, Hugh G./Whitehorn, Alan (Hg.): Party Politics in Canada, Scarborough (Ont.), 381-397.

Harrison, A. W., Rainer Jr, R. K., Hochwarter, W. A., \& Thompson, K. R. (1997). Testing the SelfEfficacy-Performance Linkage of Social-Cognitive Theory. The journal of social psychology, 137(1), 79-87.

Hirschman, A. O. (1970). Exit, voice, and loyalty: Responses to decline in firms, organizations, and states (Vol. 25): Harvard university press.

Hulin, C. (1991). Adaptation, persistence, and commitment in organizations.

Ismail Al-Alawi, A., Yousif Al-Marzooqi, N., \& Fraidoon Mohammed, Y. (2007). Organizational culture and knowledge sharing: critical success factors. Journal of knowledge management, 11(2), 22-42.

Ivancevich, J. M., \& Matteson, M. T. (1980). Stress and work: A managerial perspective: Scott Foresman.

Kacmar, K. M., \& Ferris, G. R. (1991). Perceptions of organizational politics scale (POPS): Development and construct validation. Educational and Psychological Measurement, 51(1), 193-205.

Kacmar, K. M., Bozeman, D. P., Carlson, D. S., \& Anthony, W. P. (1999). An examination of the perceptions of organizational politics model: Replication and extension. Human relations, 52(3), 383416.

Kanner, A. D., Coyne, J. C., Schaefer, C., \& Lazarus, R. S. (1981). Comparison of two modes of stress measurement: Daily hassles and uplifts versus major life events. Journal of behavioral medicine, 4(1), $1-39$.

Katz, D., \& Kahn, R. L. (1978). The social psychology of organizations (Vol. 2): Wiley New York.

King, M., \& Van den Berg, O. (1991). The politics of curriculum: structures and processes: Centaur Publications.

Kyriacou, C. (2001). Teacher stress: Directions for future research. Educational Review, 53(1), 27-35.

Lazarus, R. S. (1993). From psychological stress to the emotions: A history of changing outlooks. Annual review of psychology, 44(1), 1-22. 
Lewin, K. (1936). A DYNAMIC THEORY OF PERSONALITY: SELECTED PAPERS. The Journal of Nervous and Mental Disease, 84(5), 612-613.

Madison, D. L., Allen, R. W., Porter, L. W., Renwick, P. A., \& Mayes, B. T. (1980). Organizational politics: An exploration of managers' perceptions. Human relations, 33(2), 79-100.

Marshall, J., \& Cooper, C. L. (1976). The mobile manager and his wife. Management Decision, 14(4), 179224.

Mintzberg, H. (1985). The organization as the political arena. Journal of management studies, 22(2), 133154.

Mossholder, K. W., Bedeian, A. G., Norris, D. R., Giles, W. F., \& Feild, H. S. (1988). Job performance and turnover decisions: Two field studies. Journal of management, 14(3), 403-414.

Mowday, R. T., Steers, R. M., \& Porter, L. W. (1979). The measurement of organizational commitment. Journal of Vocational Behavior, 14(2), 224-247.

Organ, D. W. (1990). The motivational basis of organizational citizenship behavior. Research in Organizational Behavior, 12(1), 43-72.

Parker, D. F., \& DeCotiis, T. A. (1983). Organizational determinants of job stress. Organizational behavior and human performance, 32(2), 160-177.

Parker, R. B. (1993). The Politics of Miscalculation in the Middle East: Georgetown University Press.

Perrewé, P. L., \& Zellars, K. L. (1999). An examination of attributions and emotions in the transactional approach to the organizational stress process. Journal of organizational behavior, 739-752.

PFEFFER, J. (1981). Management as Symbolic Action: The Creation and Maintenance of Organizational Paradigms. Research in Organizational Behavior, 13, 1-52.

Poon, J. M. (2006). Trust-in-supervisor and helping coworkers: Moderating effect of perceived politics. Journal of Managerial Psychology, 21(6), 518-532.

Randall, M., Cropanzano, R., Bormann, C., \& Birjulin, A. (1994). The relationship of organizational politics and organizational support to employee attitudes and behavior. Paper presented at the annual meeting of the Academy of Management, Dallas, TX.

Rashid, U., Karim, N., Rashid, S., \& Usman, A. (2013). Employee. Asian Journal of Business Management, 5(4), 348-352.

Rosen, C. C., Levy, P. E., \& Hall, R. J. (2006). Placing perceptions of politics in the context of the feedback environment, employee attitudes, and job performance. Journal of Applied Psychology, 91(1), 211-220.

Rusbult, C. E., Campbell, M. A., \& Price, M. E. (1990). Rational selective exploitation and distress: employee reactions to performance-based and mobility-based reward allocations. Journal of Personality and Social Psychology, 59(3), 487.

Rusbult, C. E., Lowery, D., Hubbard, M. L., Maravankin, O. J., \& Neises, M. (1988). Impact of employee mobility and employee performance on the allocation of rewards under conditions of constraint. Journal of Personality and Social Psychology, 54(4), 605.

Rusbult, C., \& Lowery, D. (1985). When bureaucrats get the blues: Responses to dissatisfaction among federal employees. Journal of Applied Social Psychology, 15(1), 80-103.

Schuler, R. S. (1980). Definition and conceptualization of stress in organizations. Organizational behavior and human performance, 25(2), 184-215.

Selye, H. (1976). The stress concept. Canadian Medical Association Journal, 115(8), 718.

Tushman, M. L. (1977). A political approach to organizations: A review and rationale. Academy of management review, 2(2), 206-216.

Valle, M., \& Perrewe, P. L. (2000). Do politics perceptions relate to political behaviors? Tests of an implicit assumption and expanded model. Human relations, 53(3), 359-386.

Vardi, Y., \& Wiener, Y. (1996). Misbehavior in organizations: A motivational framework. Organization Science, 7(2), 151-165.

Vigoda, E. (2000). Organizational politics, job attitudes, and work outcomes: Exploration and implications for the public sector. Journal of Vocational Behavior, 57(3), 326-347.

Vigoda-Gadot, E., \& Kapun, D. (2005). Perceptions of politics and perceived performance in public and private organizations: a test of one model across two sectors. Policy \& Politics, 33(2), 251-276. 
Whitener, E. M. (2001). Do "high commitment" human resource practices affect employee commitment? A cross-level analysis using hierarchical linear modeling. Journal of management, 27(5), 515-535.

Witt, L. (1998). Enhancing organizational goal congruence: A solution to organizational politics. Journal of Applied Psychology, 83(4), 666.

Witt, L. A., Andrews, M. C., \& Kacmar, K. M. (2000). The role of participation in decision-making in the organizational politics-job satisfaction relationship. Human relations, 53(3), 341-358.

Wright, T. A., \& Cropanzano, R. (1998). Emotional exhaustion as a predictor of job performance and voluntary turnover. Journal of Applied Psychology, 83(3), 486. 